\title{
Structural Properties of Steel-glulam Composite Column*1
}

\author{
Sang Sik Jang ${ }^{* \dagger}$, Yun Hui Kim*2, and Il Joong Shin*2
}

\begin{abstract}
A new green home designed to save money while at the same time saving the environment with some of the finest green features available in the market. Composite column composed of structural steel and structural glued laminated timber is avery Eco-friendly building products for design building because that use recycled or second hand. For compare to compressive strength of structural glued laminated timber (glulam), structural steel, and composite column (steel-glulam), tested compressive strength of each specimen. 1) structural glued laminated timber : Theoretical compressive strength is $151.6 \mathrm{kN}$ similar to elastic limits. 2) structural steel ( $\mathrm{H}$ type) : Theoretical compressive strength is $148.2 \mathrm{kN}$ little under the elastic limits. 3) structural steel (D type) : Theoretical compressive strength is $147.3 \mathrm{kN}$ upper than the elastic limits. 4) composite column : Actual elastic limits are about $600 \mathrm{kN}$. Result in, composite column improve compressive strength of Structural steel column and provide structural stability of the building.
\end{abstract}

Keywords : structural steel, structural glued laminated timber (glulam), composite column

\section{INTRODUCTION}

Inthe last decade, the wood-framed housing has grown and expanded into new markets in Korea. The fact remains that most of architects use steel structure for design building because they are familiar with steel structure. Steel structure is widely accepted in industrial and commercial construction. Increasing long-span and multi-story building require mechanical properties greater than criteria. Also, due to concerns about the environment, now is the time to make "Green-House" eco-friendly and reduce carbon footprint. Many studies are on saving the building Energy to cope with FCCC (Framework convention on Climate Change). Structural steel and Structural glued laminated timber can be a very Eco friendly building product for new homes or extensions, even more so when we use recycled or second hand. Most Korean architects have low credibility of the lumber because they consider that lumber is not a structural product. For expending wood- framed housing market, should make a new system to correct the flaws. Upper than 4 story buildings need to performance verification of structural properties defined the construction standard for light wood framed structure on KS F 9002.

*1 Received on April 22, 2010; accepted on July 7, 2010

*2 Department of Bio-based Materials, Faculty of Agriculture and Life Sciences, Chungnam National University, Daejeon 305-764, Korea

† Corresponding author : Sang Sik Jang (e-mail: ssjang@cnu.ac.kr) 
Table 1. Allowable stress of glulam 10S-34B grade (Unit : $\mathrm{N} / \mathrm{mm}^{2}$ )

\begin{tabular}{cccccc}
\hline$F_{b}$ & $F_{c}$ & $F_{t}$ & $F_{v}$ & $F_{c \perp}$ & $E$ \\
\hline \hline 11 & 9.5 & 8 & 2 & 3.5 & 8,000 \\
\hline
\end{tabular}

Many studies looking for high capacity hybrid materials to get developed building design. Yang (2006) mentioned new adhesive system of composite column composed of structural steel and structural glued laminated timber. We expect that composite column (steel-glulam) provide high mechanical properties for long-span and multi-story building design. In this study, composite column compare to compareto compressive strength of structural steel, structural glued laminated timber (glulam) and composite column.

\section{MATERIALS and METHODS}

\subsection{Structural Glulam}

Korean Larch was used to manufacture glulam in accordance with KS F 3021. Structural glulam was produced using the 10S-34B grade and all the laminations were selected to have the same machine stress grade which was E11 or greater. Table 1. Shows allowable stress of glulam specified in KS F 3021. During manufacture, resorcinol resin adhesive was applied at the rate of $250 \mathrm{~g} / \mathrm{m}^{2}$ and at the pressure of $7 \sim$ $10 \mathrm{~kg} / \mathrm{cm}^{2}$. Size of cross section is $150 \times 150$ $\mathrm{mm}$ and length is $3,000 \mathrm{~mm}$.

The theoretical formula used to calculate the compressive strength of structural glued laminated timber (glulam). Design value of compressive strength should considered stability factor, specified strength in compression parallel to grain and cross-sectional area. Calculated design compressive strength of the structural glued laminated timber is $151,560 \mathrm{~N}$.
Table 2. Strength of structural steel SS400

\begin{tabular}{ccc} 
grade & & $($ Unit : N/mm $)$ \\
\hline $\mathrm{F}_{\mathrm{y}}$ & $\mathrm{F}_{\mathrm{t}}$ & $\mathrm{E}$ \\
\hline \hline 235 & 400 & 206,000 \\
\hline
\end{tabular}

Table 3. Strength of structural steel SPSR 400

\begin{tabular}{ccc} 
grade & & $\left(\right.$ Unit : N/mm $\left.{ }^{2}\right)$ \\
\hline $\mathrm{F}_{\mathrm{y}}$ & $\mathrm{F}_{\mathrm{t}}$ & $\mathrm{E}$ \\
\hline 235 & 400 & 206,000 \\
\hline
\end{tabular}

\subsection{Structural Steel}

\subsubsection{H Type}

According to KS D 3503, structural steel was produced using the SS400 grade. Table 2. Shows strength of Structural steel specified in KS D 3503. Web and flange of Structural steel $(\mathrm{H}$ type) are $6.5 \mathrm{~mm}$ and $9 \mathrm{~mm}$. Size of cross section is $125 \times 125 \mathrm{~mm}$ and length is $3,000 \mathrm{~mm}$. Cross-sectional area is $3,031 \mathrm{~mm}^{2}$. Compressive strength for design should consider slenderness variables and specified strength in compression parallel to grain. Calculated design value compressive strength of the structural steel (H type) is $148,243 \mathrm{~N}$.

\subsection{2. $\square$ Type}

According to KS D 3568, structural steel was produced using the SPSR400 grade. Table 3. shows strength of Structural steel specified in KS D 3503. Size of cross section is $80 \times 80$ $\mathrm{mm}$ and length is $3,000 \mathrm{~mm}$. Thickness of Structural steel ( $\square$ type) is $3.2 \mathrm{~mm}$. Cross-sectional area is $956.7 \mathrm{~mm}^{2}$. Calculated design value compressive strength of the structural steel ( $\square$ type) is $136,007 \mathrm{~N}$.

\subsection{Composite Members}

Structural glulam was used to manufacture 
Table 4. Size of composite columns selected for strength

\begin{tabular}{ccc}
\hline Kind of specimen & $\begin{array}{c}\text { Sizes of structural steel } \\
(\text { depth } \times \text { width } \times \text { length })\end{array}$ & $\begin{array}{c}\text { Sizes of specimen } \\
(\text { depth } \times \text { width } \times \text { length })\end{array}$ \\
\hline \hline $\begin{array}{l}\text { H-section steel column with glulam cover } \\
\text { for compressive tests }\end{array}$ & $125 \times 125 \times 3,000 \mathrm{~mm}$ & $250 \times 250 \times 3,000 \mathrm{~mm}$ \\
$\begin{array}{l}\square \text {-section steel column with glulam cover } \\
\text { for compressive tests }\end{array}$ & $80 \times 80 \times 3,000 \mathrm{~mm}$ & $200 \times 200 \times 3,000 \mathrm{~mm}$ \\
\hline
\end{tabular}

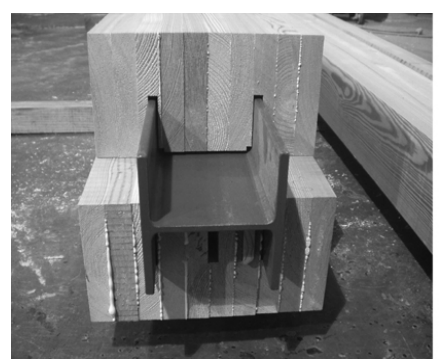

(a)

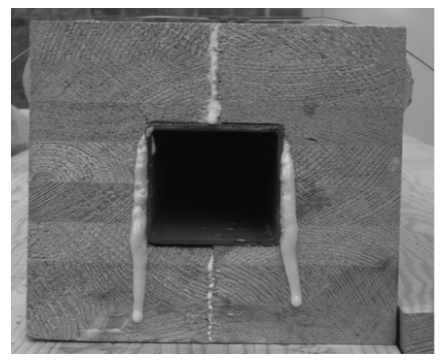

(b)

Fig. 1. (a) steel H column covered by glulam and (b) steel $\square$-column covered by glulam.

composite member as a cover on structural steel. Steel $\mathrm{H}$ and $\square$-section steel tube act as a structural frame. Resorcinol resin adhesive applied to glue steel and glulam. Section of the composite members are arranged in Fig. 1. Table 4 demonstrates the size of structural materials selected for strength and fire tests.

\subsection{Strength Tests}

5 specimens for each member used to evaluate the mechanical properties of composite columns. Using the LVDT, displacement of
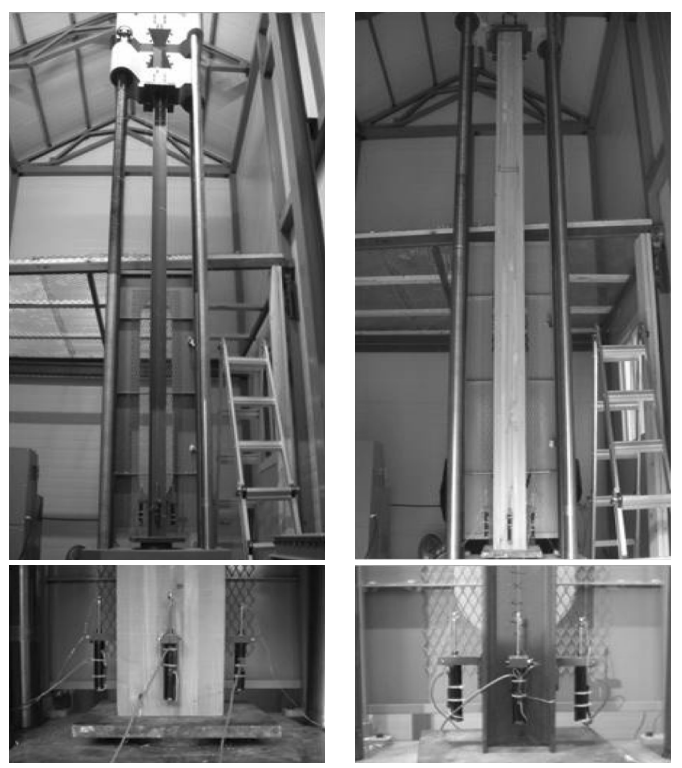

Fig. 2. Compressive test for glulam, structural steel and composite column.

composite members measured during the compression test. For measure deformation of column, LVDT set up $180 \mathrm{~mm}$ from bottom edge. Using an elasticity line join 2,720 mm span. The compressive test parallel to the grain were performed by a Universal-type testing machine. The specimen is supported near the butt and tip, and a load is applied at the ground line by the moving head of the mechanical testing machine. The average loading speed is $9.80 \mathrm{~N} / \mathrm{mm}^{2}$ per minute. All deflection curves were obtained from the compressive test, and then the ultimate compressive strengths parallel to the grain were calculated from the ultimate load. 


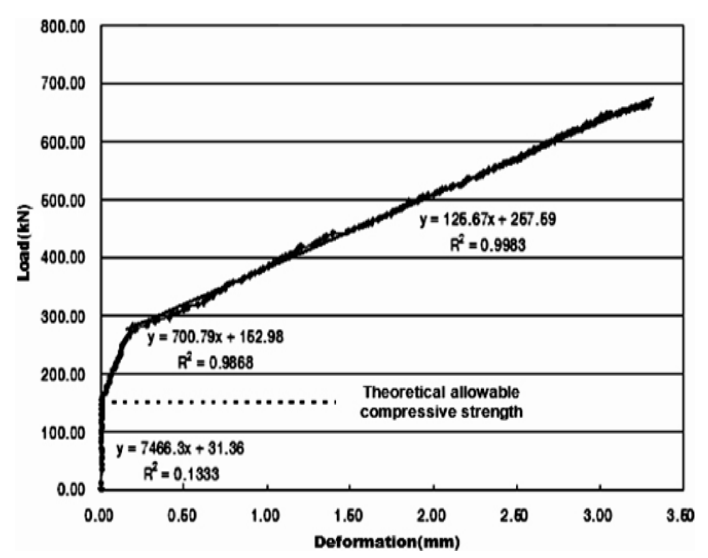

Fig. 3. Compressive strength of glulam.
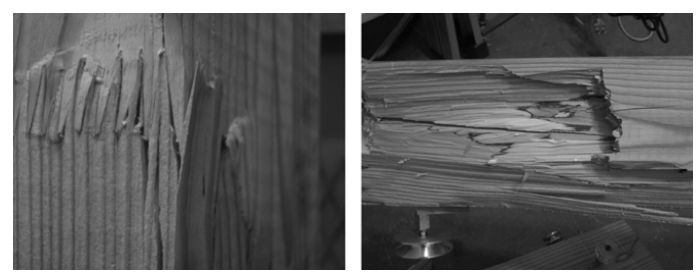

Fig. 4. Failure mode of glulam.

\section{RESULTS and DISCUSSION}

\subsection{Compressive Strength of Structural Glued Laminated Timber}

Fig. 3 shows the compressive strengths of structural glued laminated timber (glulam). Theoretical design compressive strength, 151.6 $\mathrm{kN}$, similar to elasticity limits of actual compressive test. Elasticity limits of actual compressive test is $135.8 \mathrm{kN}$. Stress-strain diagram separated three section. Slope of the last section is lower than other sections.

Fig. 4 is major two failure mode of structural glued laminated timber. One is that high strength finger - joint member digs into low strength finger-joint on the face layer of structural glued laminated timber. The other major failure mode is that column failed from bending through

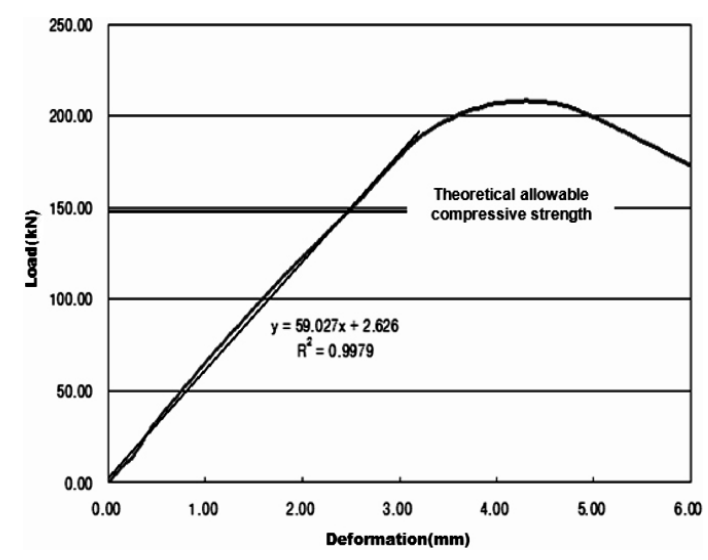

Fig. 5. Compressive strength of structural steel (H type).

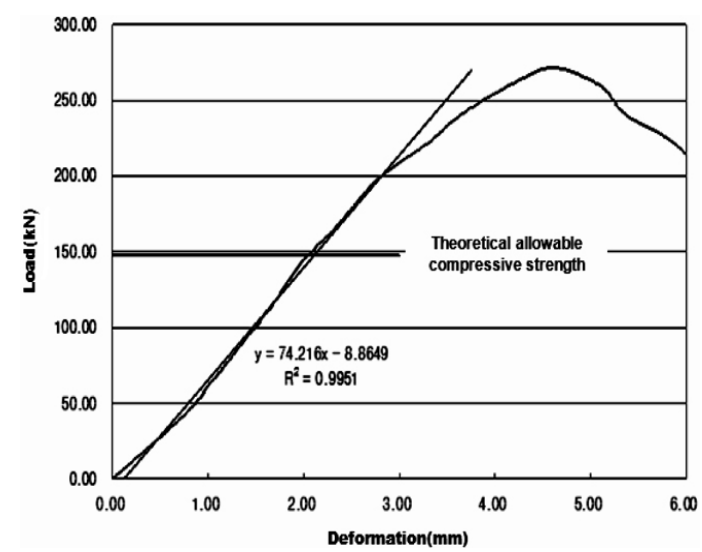

Fig. 6. Compressive strength of structural steel ( $\square$ type).

buckling.

\subsection{Compressive Strength of Structural Steel}

Theoretical design compressive strength of Structural steel (H type) is $148.2 \mathrm{kN}$. It is lower than elasticity limits of actual compressive test. According to Fig. 5, almost section include elasticity section and reach the maximum load after the elasticity section. Elasticity limits of actual compressive test is $151.9 \mathrm{kN}$.

Fig. 6. Shows compressive strength of struc- 

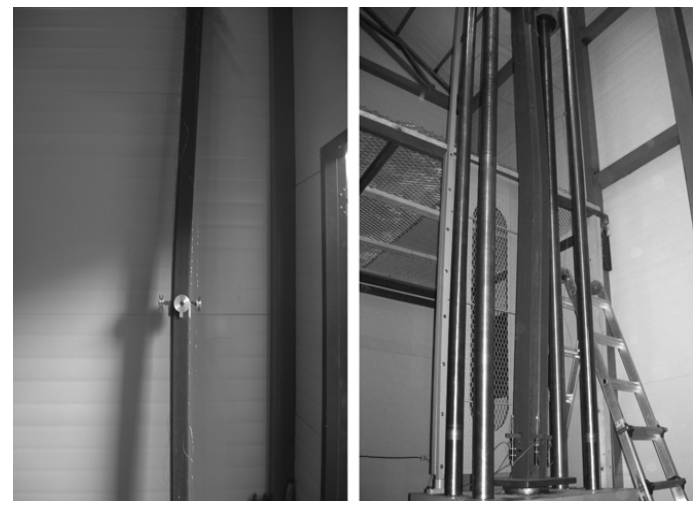

Fig. 7. Failure model of structural steel (H type, $\square$ type).

tural steel ( $\square$ type) and theoretical design compressive strength of structural steel ( $\square$ type) is $147.3 \mathrm{kN}$. Also, theoretical design compressive strength of structural steel ( $\square$ type) is lower than elasticity limits of actual compressive strength of structural steel like a structural steel (H type). Measured elasticity limits of actual compressive test is $113.7 \mathrm{kN}$ lower than elasticity limits of structural steel (H type).

Structural steel (H type) failed by buckling on Perpendicular to web. Structural steel ( $\square$ type) failed by bucking on parallel to flange. Fig. 7 shows failure model of structural steel $(\mathrm{H}$ type) and structural steel ( $\square$ type).

\subsection{Compressive Strength of Composite Column}

Fig. 8 indicates the compressive strengths of composite columns. Composite columns not shows failure mode. As shown Fig. 8, composite columns (steel-glulam) have limit of elasticity around $600 \mathrm{kN}$. It considered to calculate compressive strength of composite column. In Fig. 8, elasticity limits of composite column is higher than other members. Compressive strength of composite members were much higher than steel columns in spite of that the initial stiffness was lower than glulam columns.

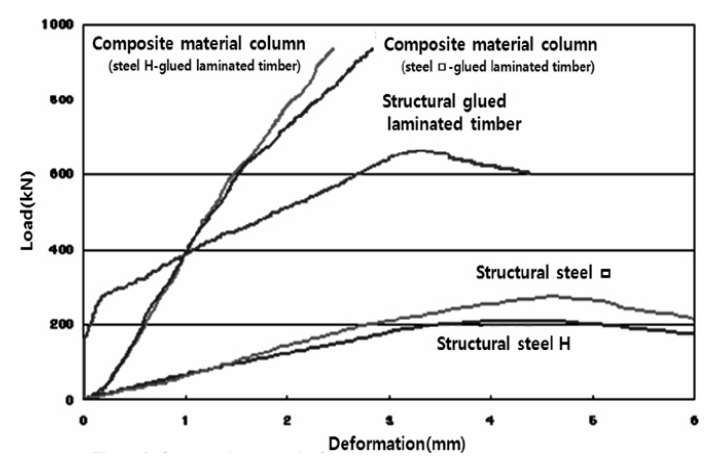

Fig. 8. Compressive strength of composite members.

\section{CONCLUSION}

Structural steel and Structural glued laminated timber can be a very Eco friendly building product for new homes or extensions, even more so when we use recycled or second hand. Structural glulam cover improved the stiffness and strength of structural steel columns under compressive loads. For compare to compressive strength, tested structural glued laminated timber, structural steel (H type), structural steel ( $\square$ type) and composite column (steel-glulam).

1) Structural glued laminated timber : Theoretical compressive strength is $151.6 \mathrm{kN}$ similar to elastic limits $(135.8 \mathrm{kN})$.

2) Structural steel (H type) : Theoretical compressive strength is $148.2 \mathrm{kN}$ littleunder the elastic limits $(151.9 \mathrm{kN})$.

3) Structural steel ( $\square$ type) : theoretical compressive strength is $147.3 \mathrm{kN}$ upper than the elastic limits $(113.7 \mathrm{kN})$.

4) Composite column : Measured elastic limits is about $600 \mathrm{kN}$. Compressive strength of composite members were much higher than steel columns in spite of that the initial stiffness was lower than structural glued laminated timber column. Also, the results expected that composite column improve design compressive strength of Structural steel column and provide structural stability of the building. 


\section{ACKNOWLEDGEMENT}

This work was supported by 'Forest Science \& Technology Projects (2007)' funded by the Korea Forest Service, Republic of Korea.

\section{REFERENCES}

1. Korean Building code and commentary. 2005.

2. Breyer, D. E., K. J. Fridley, and K. E. Cobeen. Design of Wood Structures ASD, Fourth Edition.

3. Yang, T.-H., S.-Y. Wang, M.-J. Tsai, C.-Y. Lin, and Y.-J. Chuang. 2009. Effect of fire exposure on the mechanical properties of glued laminated timber. Materials and Design 320: 698 703.

4. Jang, S. S., Y. H. Kim, and Y. I. Jang. 2009. Mechanical Properties of Composite Materials Composed of Structural steel and Structural glued laminated timber. K Wood Science and Technology 37: 300 309.

5. Breyer, D. E., K. J. Fridley, K. E. Cobeen, and D. G. Pollock. Design of Wood StructuresASD/LRFD, Sixth edition.

6. KS D 3052 Shape, dimensions, weight and toler- ances of hot-rolled steel flats, 2007.

7. KS D 3502 Dimensions, mass and permissible variations of hot rolled steel sections, 2007.

8. KS D 3503 Rolled steels for general structure, 2007.

9. KS D 3568 Carbon steel square pipes for general structural purposes, 2007.

10. KS F 3021 Structural glued laminated timber, 2005.

11. Kim, S. C. and I. S. Yang. 2006. Elasto-plastic behavior of structural laminated timber joint by flange thickness of $\mathrm{H}$ beam, Korea Society of Steel Construction. 81 2.

12. Kim, S. C., I. S. Yang, and Y. J. Moon. 2006. Elasto-plastic behavior of joint by inserting length of H-beam and structural laminated timber, Korea Society of Steel Construction. 81 2.

13. Yang, T.-H., S.-Y. Wang, M.-J. Tsai, C.-Y. Lin, and Y.-J. Chuang. 2009. Effect of fire exposure on the mechanical properties of glued laminated timber. Materials and Design 30: 698 703 .

14. Wang, Y. C. 2002. Steel and Composite StructuresBehaviour and Dsign for Fire Safety, Spon Press-Taylor \& Francis Group. 